This item was submitted to Loughborough's Research Repository by the author.

Items in Figshare are protected by copyright, with all rights reserved, unless otherwise indicated.

\title{
Geographies of finance in a globalizing world
}

PLEASE CITE THE PUBLISHED VERSION

https://doi.org/10.4337/9781785363849

PUBLISHER

Edward Elgar Publishing

VERSION

AM (Accepted Manuscript)

\section{PUBLISHER STATEMENT}

This is a draft chapter. The final version is available in Handbook on the Geographies of Globalization edited by Robert C. Kloosterman, Virginie Mamadouh and Pieter Terhorst, published in 2018, Edward Elgar Publishing Ltd https://doi.org/10.4337/9781785363849. The material cannot be used for any other purpose without further permission of the publisher, and is for private use only.

\section{LICENCE}

All Rights Reserved

\section{REPOSITORY RECORD}

Bassens, David, and Michiel Van-Meeteren. 2018. "Geographies of Finance in a Globalizing World". Loughborough University. https://hdl.handle.net/2134/37038. 


\title{
Geographies of finance in a globalizing world
}

\author{
David Bassens and Michiel van Meeteren
}

\author{
Published as: Bassens, D and Van Meeteren, M (2018) Geographies of finance in a \\ globalizing world. In: R.C. Kloosterman, V. Mamadouh and P. Terhorst (eds), Handbook on \\ the Geographies of Globalization. Cheltenham, Edward Elgar, 248-267
}

\section{INTRODUCTION: FINANCIAL GLOBALIZATION}

On 15 September 2009, Lehman Brothers, a big Wall Street investment bank, filed for bankruptcy. The bank had become heavily involved in home mortgage markets as packagers, sellers, and investors of mortgage debt in the United States. Unable to attract money in financial markets, Lehman Brothers was forced out of business. This closure, however, proved to be only the beginning of a banking crisis that would almost immediately spread across the Atlantic through deep connections between European and US banks. Yet, this still did not end the story. In the European Union (EU), as in the US, uncertainty about exposure to US mortgage markets led to a credit crunch, a near to complete freezing up of the credit flows between banks. As many banks were financed via these shortterm schemes, the credit crunch generated acute liquidity problems, and the potential threat of collapse for European banks. Subsequently, EU governments stepped in with guarantees or fresh capital injections in an effort to save the financial system from the collapse of 'systemic' banks, most of which had a Northern European signature. This move stabilized the northern 'core' of the EU. However, by 2009 it had become clear that the initial uncertainty about US mortgage market exposure had morphed into financial market uncertainty about the ability to pay of the net-debtor states in what was soon dubbed 'the periphery' of Europe (or GIPSI: Greece, Ireland, Portugal, Spain, and Italy). What started as a mortgage market crisis in the US had travelled to become a European banking crisis and, in the end, took hold of Europe as a sovereign debt crisis from which the EU still had to recover a decade after the crisis emerged.

The above sketch of the inception and spread of the North Atlantic Financial Crisis (Jessop, 2015) is emblematic of a condition of financial globalization, a process characterized by the growing range and depth of financial relations enshrined in a global financial system that supersedes the international state system. The magnitude of the global financial system is hard to fathom due to its offshore character and the incomplete geographic coverage of indicators developed by key regulatory institutions. Still, as per 2017, the most recently available information indicates that cross-border bank claims amounted to 79 trillion US dollars (BIS, 2017), while derivatives markets and the murky shadow banking system amounted to as much as 544 trillion US dollars (BIS, 2016) and 137 trillion US dollars (FSB, 2015) respectively. Even if we considered these as modest estimates (excluding foreign direct investments and portfolio investments), the size of the global financial system is by now about ten times the size of the global economy, which was estimated at 74 trillion US dollars in 2015 (World Bank, 2017). While the cross-border character of finance is nothing new, the concept of financial globalization captures the tremendous growth of these financial exchanges in recent decades. Moreover, financial globalization signals the difference from earlier efforts to contain and regulate what was formerly known as the international financial system as financial globalization largely escapes the financial and monetary governance capacities of the state system (Strange, 1994).

The main purpose of this chapter is to provide an overview of the main drivers of financial globalization. What is it about finance that allows its globalization to take place so rapidly and deeply? In the next section we contend that a main answer lies in the inherent capacity of finance to overcome space and time constraints. Finance appears to produce space, yet, co-constitutively, geographic-institutional variegation feeds back into how finance operates. Hidden beneath this abstract mechanism of time-space compression (Harvey, 1989), lie concrete geographies of finance are to an important extent co-evolutionary with pre-existing geographies of knowledge, law, and power. As the resulting variegation raises important analytical questions, the third section provides an overview of how financial geographers study this process from the perspectives of international financial centres, firms, flows, and products. The fourth section examines the history of post-1945 European financial integration to illustrate how European states have sought ways to contain and benefit from financial globalization, a process that, 
paradoxically, has been fundamental in deepening uneven development on the continent. The final section concludes, with a research agenda and a plea to give space a central focus in future studies of finance.

\section{THE CO-CONSTITUTION OF FINANCE AND SPACE}

In capitalism, the decision about 'where to put your money' is usually determined by the ability of capital to generate a surplus. As the amount of capital in the world increases, the surplus-generating opportunities needed for stable accumulation increases in a compounding rate. In absolute terms, the 2014 world economy would have to grow 333 times more than in 1970 to sustain a normal rate of accumulation (six billion in 1970, two trillion in 2014, see Harvey, 2014: 228). Somewhat counter intuitively, a capitalist crisis emerges when more money is around than can be profitably invested, frustrating the system's need for ongoing expansion. The result is a 'wall of money', restlessly and sometimes desperately seeking normal returns (Fernandez and Aalbers, 2016), logically resulting in (trading of) financial instruments to reap future profits and defer risks to others - a condition called 'financialization' (Arrighi, 1994[2010]). In order to gain a surplus, capital needs to become mobile to switch easily from one circuit of value to another, yet not all forms of capital can do this with the same ease. Capital, a process of value in motion, appears in three forms, which display varying geographical mobilities: the productive, commodity, and financial capital forms. Harvey (2013: 37-40) proposes the metaphor of a butterfly to illustrate the capital accumulation cycle that links the three capital moments. Productive capital (e.g. factories, infrastructure, and machinery) is hardly mobile (like an egg or a chrysalis), while commodity capital (i.e. sellable goods and services) is only mobile to a limited extent (like a caterpillar). Finance capital (i.e. credit), however, is free like a butterfly to relocate and become part of a different circuit. Hence the pivotal role of finance capital for globalization: only in its financial form can capital move around to become part of the most profitable circuit. This capacity to become mobile has enabled time-space compression with financial products being traded globally on the nanosecond.

The structural tendencies described above can result in many different concrete outcomes, depending how actors act upon them (Van Meeteren and Bassens, 2018). Globally operating finance has crystallized into a particular structure: money does not flow everywhere with the same ease, yet sticks to certain places 'like mercury' (Clark, 2005). At the same time, investment opportunities are not simply waiting to be discovered, but are socially constructed by financial intermediaries who produce geographical narratives (i.e. economic geographies) on where to invest next (Lee, 2002). Concrete geographies thus hinge upon how actors in particular places are able to (re)combine knowledge, legal, and power resources (Van Meeteren and Bassens, 2016). First, gaining from financial globalization requires knowledge about profitable invest- ment opportunities. For finance to 'work' across the borders of different political economies, different kinds of expertise have to be combined. The ability to interpret financial information is not ubiquitous, but instead tends to be concentrated in a limited number of places, where actors can marshal agglomerated resources, and an advanced division of labour of specialized service firms and their networks (Bassens and Van Meeteren, 2015). Combined, these resources enable interpretation of information flows, innovation into new markets and product areas, and representation of financial power (Amin and Thrift, 1992). Consequently, the more complicated and advanced financial products - those that are most attractive in the context the 'wall of money problem' - tend to be only accessible from the larger, betterconnected financial centres (Clark and O' Connor, 1997). Moreover, access to knowledge is not only a question of 'being there', one also needs to be socialized in the profession to have the cognitive repertoire and the social and cultural resources to access this market information.

Second, global finance is crucially mediated by legal geographies. Financial assets are contracts concerning claims on future revenues, the value of which depends on their legal vindication, that is, the plausibility that the contract will be honoured at a later date (Pistor, 2013). The globalization of finance has coincided with the emergence of an expanding and deepening set of free trade rules (e.g. embodied in the World Trade Organization or regional blocks such as the EU) that seek to competitively (re)regulate, and not such much deregulate, cross-border financial exchanges. However, the world is anything but a singular legal space and different jurisdictions remain marked by different legal regimes. It is the law that helps to create, segment, and demarcate a mosaic of markets over the world (Christophers, 2015). Moreover, legal regimes overlap, creating innumerable loopholes of legal arbitrage, once territories with slightly different legal regimes are combined (Sassen, 2013). Intermediaries, such as big global law firms, do not only help facilitate actors to traverse these boundaries and exploit the loopholes, but they are also active in changing legal spaces to their and their clients' advantage (Faulconbridge and Muzio, 2015).

Third, power relations not only mediate the way global finance operates, but also who gains from its practices. Concerning the former, the relations between financial actors are influenced by the relative position of the nation- 
states from which they operate in the inter-state system. Even though financial sector interests have become to a degree disembedded from 'territorial' interests of their hosting nation-states, the way the global financial system is structured is still reminiscent of power relations between states. For instance, the period of American politicaleconomic hegemony after the Second World War was matched by the growing globalization and influence of its private financial institutions. Similarly, the growing weight of China in the global economy currently translates in the growing weight and range of its state-related banks and sovereign wealth funds (Haberly, 2011). Concerning the spoils of financial globalization, it appears these are distributed unevenly between the too-big-to-fail banks, and the wider public (be it states or taxpayers), the latter having borne most of the cost of systemic failure in 2008. Also within the financial sector, some animals are more equal than others: when push comes to shove, some legal claims are more likely to be honoured. Generally speaking, laws regarding financial resolution tend to be flexible and negotiable when the core of the financial system benefits and remorseless when the powerless or the periphery have to pay up (Pistor, 2013: 317). Wójcik (2013) shows how banks in the dyad London-New York, largely responsible for the financial crisis of 2008, went back to reaping exuberant profits in no time. Part of the power of these financial intermediaries is structural in nature, as collectively they act as obligatory passage points for all those - including citizens of capitalist states - in need of accumulation for their private or collective household pension and schemes.

\section{ANALYZING FINANCIAL GEOGRAPHIES}

The discussed mechanisms of financial globalization come together in four analytical perspec- tives utilized by financial geographers who study the global financial system.

First, studies of International Financial Centres (IFCs) analyze the agglomeration of financial activities. A key debate here regards to what extent contemporary IFCs are a path-dependent result of long-term historical development. The study of the rise and fall of European financial centres (see e.g. Arrighi, 1994[2010]; Cassis, 2006) reveals that cycles of economic expansion and decline coincide with geographical shifts in the leading IFCs. Financial geographers are interested in how these histories provide a heritage of place-based institutions and regimes (King, 1990). While path-dependencies matter, the ever-expanding role of Information and Communication Technologies (ICT) has helped producing a global, electronically wired financial system, in which many second- and third-tier financial centres have seen their position weakened (Engelen, 2007). Yet, while many popular and policy debates interpret IFC formation as a zero-sum game with harsh implications for smaller centres, geographers have offered compelling evidence that financial intermediation depends on a spatial division of labour. Different IFCs and offshore financial centres perform complementary and niche roles in the global financial system (Lee and Schmidt-Merwede, 1993; Van Meeteren and Bassens, 2016) in both mature (Faulconbridge, 2004), and emerging (Lai, 2012) markets.

Second, financial geographers have studied the spatial organization of financial intermediaries. As these firms are the enablers of financial globalization, it is relevant to inquire about the spatial strategies of financial intermediaries and an array of supporting producer services. How do these firms organize global work and govern their global activities as part of their business model? World city network research has systematically mapped out the connectivities of financial centres, based on the insertion of financial, accounting, management consultancy, advertising, and law intermediaries in global urban networks (Taylor and Derudder, 2016). Changing ownership structures - due to mergers and acquisitions in these sectors (Zademach and Musil, 2014) - in turn affect the positionality of IFCs that host these intermediaries in the world city network. Other studies focus on the governance geographies of institutional investors such as pension funds (Hebb and Wójcik, 2005), sovereign wealth funds (Dixon and Monk, 2014), niches such as Islamic finance (e.g. Bassens et al., 2011), private equity and venture capital (Martin et al., 2002), and financial technologies that may disrupt the financial sector (Hendrikse et al., 2018). Financial geography also offers in-depth qualitative studies of the narratives on the importance of global expansion of financial institutions, which started to flourish in a context of relaxing antitrust rules and shareholder capitalism in the financial sector (Van Meeteren and Bassens, 2018). Ultimately, the firm-based perspective raises questions about the extent to which financial intermediaries are not only the executers, but also targets of corporate financialization.

A third perspective deals with the spatialities and power relations of credit flows and the financial products and techniques that allow capital to move across borders. Unfortunately, financial geographies, in the strict sense of mapping financial flows, are uncommon, despite the availability of official data on Foreign Direct Investment (FDI) and cross-border bank holdings. Still, geographers have used these data sources to understand cross-border interdependencies between banking systems (Bassens et al., 2013) or to disclose the footprint of the offshore system (Haberly and Wójcik, 2015). The fundamentally geographical nature of the global financial crisis of 2008 
gave an impetus to this line of inquiry as a global web of financial obligations ground to a standstill with disastrous effects on economies and societies. Financial geographers have subsequently become interested in the techniques that have allowed the crisis to spread between different areas of the financial system. The technique of the bundling and repackaging of assets known as 'securitization' emerged as key in this context. Its geographies of variegated implementation and diffusion have come to constitute an important point of attention (Aalbers et al., 2011).

Fourth, financial geographers have studied the territorially variegated outcomes of financial globalization. The global financial system is embedded in formal (e.g. legal systems, regulatory frameworks) and informal institutions (e.g. relating to business cultures) that are context-bound (Peck and Theodore, 2007). Authors conceptualize these differences as a process of unfolding variegated financialization, which plays out differently depending on the context (see e.g. Fernandez and Aalbers, 2016). Typically, this is examined at the national scale where particular finance-society relations are hypothesized. Often, geographers make an ideal-typical distinction between bank- based regimes and capital-market based regimes, even though that distinction has increasingly blurred in contemporary economies (Hardie and Howarth, 2013). Geographers working from this institutional perspective have been interested in grasping the changes in national financial systems under globalization, for instance mapping cross-border stock listings (Wójcik, 2011). Alternatively, geographers have wondered how (national) markets are socially constructed as an investment category, under the banner of emerging markets research (see Bassens, 2012; Heinemann, 2016). This construction of geographically articulated markets raises fundamental questions about how these markets relate to political-economic scales such as the EU, a question to which we will now turn.

\section{ILLUSTRATION: EUROPEAN FINANCIAL INTEGRATION}

The incessant drive for finance capital's spatial expansion presents state actors, such as politicians and regulators, with a conundrum. While state actors seek to stabilize their economies in spite of the crisis-prone volatilities of the global financial system, they also have a desire to encapsulate financial globalization to their benefit. This necessitates a scalar fix (Cox, 2002): the construction of a scale that can withstand the geographical upscaling and acceleration of the global financial system. A key example of such 'scalar fixing' is the deepening of European financial and monetary integration over the past four decades. In order to ensure the political-economic stability of the present-day EU, it became necessary to shield the European economy from currency volatility after the collapse of the 1944-1973 transatlantic Bretton Woods regime (Strange, 1994). Bretton Woods was largely designed by the United States to direct the power of financial globalization into re-building the defeated economies of the Second World War into a pro-US geopolitical constellation. Central mechanisms to achieve such orchestration were the restriction of capital movements and pegging currencies to the dollar (Varoufakis, 2015[2011]). In Northern Europe, this created spaces in which national financial and banking systems could flourish relatively shielded from foreign competition (Lee and Schmidt-Merwede, 1993). Meanwhile, tensions in the Bretton Woods system helped to lay the foundations of the contemporary global financial system with a crucial role cut out for the City of London and its Commonwealth offshore satellites (Roberts, 1995). When the BrettonWoods regime finally collapsed in 1973, the European refuge from the volatility of financial globalization came to an end and immediately raised the stakes of a European scalar fix of financial integration. From 1973 onwards, an increasing number of regulations and institutions have been issued to promote free and frictionless movement of capital within what in 1993 became the EU (Maes, 2007). The North Atlantic Financial Crisis of 2008 accelerated this process considerably as the power of the European Central Bank was strengthened, movements towards further financial integration were initiated, and the pressure on member states that 'treaded outside the commonly agreed' budgetary rules were increased (Matthijs and Blyth, 2015).

However, the struggle to construct a European scalar fix in fact has exacerbated uneven development within the continent (Bassens et al., 2013). A growing series of EU initiatives towards monetary, banking and capital market union have diminished legal fragmentation within the EU. This homogenization of legal geographies is predicted to affect the division of labour between IFCs across Europe (Faulconbridge et al., 2007). Although some regional specializations - for instance Vienna as a centre of East-European finance (Zademach and Musil, 2014) - have emerged, generally European financial integration has strengthened the position of London, Paris, and Frankfurt at the expense of smaller centres, such as Amsterdam and Brussels (Derudder et al., 2011). Although the more intricate knowledge geographies found in the larger IFCs have become more important, local knowledges have not lost their relevance altogether. Nevertheless, core-periphery relations within Europe have become strained as financial integration has mostly benefited expansion by core banks into the periphery during successive waves of mergers and acquisitions. In 2015, only three out of the 20 largest European commercial banks came from the GIPSI countries: Banco Santander and BBVA in Spain and Unicredit in Italy (Goddard et al., 2016: 113), none 
were headquartered in Eastern Europe. Moreover, IFCs in the periphery are predominantly conduits channelling in capital coming from the EU's Northern members (Karreman, 2009). After the inception of the Euro and until 2008 banks from core countries were key in financing credit-led economic development in the GIPSI countries (Bassens et al., 2013). Pre-crisis geographical expansion also came with the use of new techniques such as securitization to keep assets of the books, increase bank leverage, and churn out higher profits (Wainwright, 2015). Lingering national legal differences pertaining to securitization (Thiemann, 2012), however, left banks unevenly exposed to the crisis, producing a banking crisis geography skewed to Northern Europe. Yet, as the crisis morphed into its sovereign debt phase, GIPSI countries were ultimately the ones facing liquidity issues, as refinancing their debt with core banks had become increasingly challenging. Since then, debt asymmetries have augmented the political dominance of the EU's core countries over the periphery (Varoufakis, 2015[2011]). This is reflected in the way in which the Eurozone crisis is understood in the various EU jurisdictions with representatives of the Northern countries likely to 'blame the periphery' for their own troubles (Engelen et al., 2011). Moreover, some EU member states have more influence on how things are organized at the EU scale than others, giving rise to ever-louder accusations that the scalar fix of European financial integration boils down to a form of financial imperialism (Hadjimichalis, 2011). Greece, for instance, has been repeatedly denied the budgetary flexibility by the EU institutions that was granted to Germany in 2003 to pay for its reunification in the 1990s (Heipertz and Verdun, 2004; Varoufakis, 2015[2011]: 201-203). In sum, despite the EU Institutions' enduring rhetoric of economic convergence, the political-economic exercise in containing and benefitting from financial globalization through fixing it at the EU scale has in reality produced a fundamentally uneven financial geography within its spatial confines.

\section{CONCLUSION}

This chapter has highlighted the fundamentally co-constitutive nature of finance and space. While finance capital breeds globalization in its search for profitable outlets, a global financial system has emerged with a traceable spatial footprint. It is the geography of this socio-spatial structure that financial geographers aim to pin down to understand its variegated entanglements with polities, economies, and societies across the globe. To do so in the current conjuncture is intriguing because of at least three processes of ostensible disruption. First, we are entering a period where the two states harbouring the leading IFCs - US and Wall Street, UK and The City - are renegotiating their interaction with the global economy while new geo-economic players are entering the scene. At the time of writing, the US president Donald Trump is proclaiming a future of stringent economic protectionism, whereas UK's Prime Minister Theresa May is executing the Brexit from the European Union. Meanwhile, besides being recipients of finance capital, key emerging economies such as China are by now also instigators of financial globalization themselves, with an important role for sovereign investments into Europe and the US. Second, current geo-financial shifts run parallel with rapid technological developments in the financial industry, a process referred to as the rise of Financial Technology (FinTech). The digitization of finance carries the promise of a more decentralized financial power outlay as new players beyond the big bank shortlist might rejuvenate smaller IFCs. Simultaneously, counter currents in the banking world seem to suggest that FinTech may very well be a strategic asset in maintaining existing banking oligopolies in a limited number of IFCs (Hendrikse et al., 2018). Third, despite the confluence of a growing wall of money and citizen dependence on accessing the debt-driven global financial system for their social reproduction (Graeber, 2011), the current finance-dominated form of capitalism has failed to produce an inclusive and redistributive system. Together, these three developments raise serious questions about the spatial reproduction of the global financial system, the analysis of which, we may hope, can draw on the apparatus developed in this contribution.

\section{REFERENCES}

Aalbers, M.B., E. Engelen and A. Glasmacher (2011), “"Cognitive closure” in the Netherlands: mortgage securitization in a hybrid European political economy', Environment and Planning A, 43(8), 1779-1795.

Amin, A. and N. Thrift (1992), 'Neo-Marshallian nodes in global networks', International Journal of Urban and Regional Research, 16(4), 571-587.

Arrighi, G. (1994[2010]), The Long Twentieth Century. Money, Power and the Origins of our Times, London and New York: Verso.

Bassens, D. (2012), 'Emerging markets in a shifting global financial architecture: the case of Islamic securitization in the Gulf region', Geography Compass, 6(6), 340-350.

Bassens, D. and M. Van Meeteren (2015), 'World cities under conditions of financialized globalization: towards an augmented world city hypothesis', Progress in Human Geography, 39(6), 752-775.

Bassens, D., B. Derudder and F. Witlox (2011), 'Setting Shari'a standards: on the role, power and spatialities of interlocking Shari'a boards in Islamic financial services', Geoforum, 42(1), 94-103. 
Bassens, D., M. Van Meeteren, B. Derudder and Witlox, F. (2013), 'No more credit to Europe? Cross-border bank lending, financial integration and the re-birth of the national scale as a credit scorecard', Environment and Planning A, 45(10), 2399-2419.

Bank for International Settlements (BIS) (2016), 'Statistical release OTC derivatives statistics at end-June 2016', accessed on: 7 March 2017, https://www.bis.org/.

Bank for International Settlements (BIS) (2017), 'Summary of consolidated statistics, by nationality of reporting bank', accessed on: 7 March 2017, https://www.bis.org/.

Cassis, Y. (2006), Capitals of Capital: The Rise and Fall of International Financial Centres 1780-2009, Cambridge, MA: Cambridge University Press.

Christophers, B. (2015), 'The law's markets: envisioning and effecting the boundaries of competition', Journal of Cultural Economy, 8(2), $125-143$.

Clark, G.L. (2005), 'Money flows like mercury: the geography of global finance', Geografiska Annaler: Series B, Human Geography, 87(2), 99-112.

Clark, G.L. and K. O’Connor (1997), 'The informational content of financial products and the spatial structure of the global finance industry', in: K.R. Cox (ed.), Spaces of Globalization. Reasserting the Power of the Local, New York/London: The Guilford Press, pp. 89-114.

Cox, K.R. (2002), “'Globalization”, the "regulation approach”, and the politics of scale', in: A. Herod and M.W. Wright (eds), Geographies of Power, Placing Scale, Malden: Blackwell Publishing, pp. 85-114.

Derudder, B., M. Hoyler and P.J. Taylor (2011), 'Goodbye Reykjavik: international banking centres and the global financial crisis', Area, 43(2), 173-182.

Dixon, A. and A. Monk (2014), 'Frontier finance', Annals of the Association of American Geographers, 104(4), 852-868.

Engelen, E. (2007), “Amsterdamned'? The uncertain future of a financial centre', Environment and Planning A, 39(6), 1306-1324.

Engelen, E., R.P Hendrikse, V. Mamadouh and J.D. Sidaway (2011), 'Turmoil in Euroland: the geopolitics of a suboptimal currency area?', Environment and Planning D: Society and Space, 29, 571-583.

Faulconbridge, J.R. (2004), 'London and Frankfurt in Europe's evolving financial centre network', Area, 36(3), 235-244.

Faulconbridge, J.R. and D. Muzio (2015), 'Transnational corporations shaping institutional change: the case of English law firms in Germany', Journal of Economic Geography, 15(6), 1195-1226.

Faulconbridge, J.R., E. Engelen, M. Hoyler and J.V. Beaverstock (2007), 'Analysing the changing landscape of European financial centres: the role of financial products and the case of Amsterdam', Growth and Change, 38(2), 279-303.

Fernandez, R. and M.B. Aalbers (2016), 'Financialization and housing: between globalization and varieties of capitalism', Competition and Change, 20(2), 71-88.

Financial Stability Board (FSB) (2015), 'Global shadow banking monitoring report 2015', accessed on: 7 March 2017, http://www.fsb.org/.

Goddard, J., D.G. McKillop and J.O.S. Wilson (2016), 'Ownership in European banking', in: T. Beck and B. Casu (eds), The Palgrave Handbook of European Banking, London: Palgrave Macmillan, pp. 103-134.

Graeber, D. (2011), Debt: The First 5000 Years, New York: Melhouse House Publishing.

Haberly, D. (2011), 'Strategic sovereign wealth fund investment and the new alliance capitalism', Environment and Planning A, 43(8), $1833-1852$.

Haberly, D. and D. Wójcik (2015), 'Regional blocks and imperial legacies: mapping the global offshore FDI network', Economic Geography, 91(3), 251-280.

Hadjimichalis, C. (2011), 'Uneven geographical development and socio-spatial justice and solidarity: European regions after the 2009 financial crisis', European Urban and Regional Studies, 18(3), 254-274.

Hardie, I. and D. Howarth (2013), Market-Based Banking and the International Financial Crisis, Oxford: Oxford University Press.

Harvey, D. (1989), The Condition of Postmodernity, Cambridge MA/Oxford: Blackwell.

Harvey, D. (2013), A Companion to Marx's Capital vol 2, London and New York: Verso.

Harvey, D. (2014), Seventeen Contradictions and the End of Capitalism, Oxford: Oxford University Press.

Hebb, T. and D. Wójcik (2005), 'Global standards and emerging markets: the institutional-investment value chain and the CalPERS investment strategy', Environment and Planning A, 37(11), 1955-1974.

Heinemann, T. (2016), Relational geographies of emerging market finance: the rise of Turkey and the global financial crisis 2007', European Urban and Regional Studies, 23(4), 645-661.

Heipertz, M. and A. Verdun (2004), 'The dog that would never bite? What we can learn from the origins of the Stability and Growth Pact', Journal of European Public Policy, 11(5), 765-780.

Hendrikse, R., D. Bassens, D, M. Van Meeteren (2017), 'The Appleization of finance: Charting incumnent finance's embrace of FinTech, Finance and society, 4(2), 159-180. 
Jessop, B. (2015), 'Hard cash, easy hard credit, fictitious capital: critical reflections on money as a fetishized social relation', Finance and Society, 1(1), 20-37.

Karreman, B. (2009), 'Financial geographies and emerging markets in Europe', Tijdschrift voor Economische en Sociale Geografie, 100(2), $260-266$.

King, A.D. (1990), Global Cities, Post-Imperialism and the Internationalization of London, London and New York: Routledge.

Lai, K. (2012), 'Differentiated markets: Shanghai, Beijing, and Hong Kong in China's financial centre network', Urban Studies, 49, 12751296.

Lee, R. (2002), “"Nice maps, shame about the theory?” Thinking geographically about the economic', Progress in Human Geography, 26(3), 333-355

Lee, R., and U. Schmidt-Merwede (1993), 'Interurban competition? Financial centres and the geography of financial production', International Journal of Urban and Regional Research, 17(4), 492-515.

Maes, I. (2007), Half a Century of European Financial Integration: From the Rome Treaty to the 21st Century, Brussels: Mercatorfonds.

Martin, R., P. Sunley and D. Turner (2002), 'Taking risks in regions: the geographical anatomy of Europe's emerging venture capital market', Journal of Economic Geography, 2(2), 121-150.

Matthijs, M. and M. Blyth (eds) (2015), The Future of the Euro, Oxford: Oxford University Press.

Peck, J. and N. Theodore (2007), 'Variegated capitalism', Progress in Human Geography, 31(6), 731-772.

Pistor, K. (2013), 'A legal theory of finance', Journal of Comparative Economics, 41(2), 315-330.

Roberts, S. M. (1995), ‘Small place, big money: the Cayman Islands and the international financial system', Economic Geography, 71(3), $237-256$

Sassen, S. (2013), 'When territory deborders territoriality', Territory, Politics, Governance, 1(1), 21-45.

Strange, S. (1994), 'From Bretton Woods to the casino economy', in: S. Corbridge, R. Martin, N. Thrift (eds), Money, Power, and Space, Blackwell: Oxford,pp. 49-62.

Taylor, P.J. and B. Derudder (2016), World City Network (2nd edn), London and New York: Routledge.

Thiemann, M. (2012), “Out of the shadows?' Accounting for special purpose entities in European banking systems', Competition \& Change, 16(1), 37-55

Van Meeteren, M. and D. Bassens (2016), 'World cities and the uneven geographies of financialization: unveiling stratification and hierarchy in the world city archipelago', International Journal of Urban and Regional Research, 40(1), 62-81.

Van Meeteren, M. and D. Bassens (2018), 'Chasing the phantom of a 'global end game': the role of management consultancy in the narratives of pre-failure ABN AMRO', in: Hoyler, M., Parnreiter, C. and Watson, A. (eds), Global City Makers: Economic Actors and Practices in the World City Network, Cheltenham, UK and Northampton, MA, USA: Edward Elgar Publishing, pp. $170-191$.

Varoufakis, Y.(2015[2011]), The Global Minotaur: America, Europe and the Future of the Global Economy, London: Zed Books.

Wainwright, T. (2015), 'Circulating financial innovation: new knowledge and securitization in Europe', Environment and Planning A, 47(8), 1643-1660.

Wójcik, D. (2011), The Global Stock Market: Issuers, Investors, and Intermediaries in an Uneven World, Oxford: Oxford University Press.

Wójcik, D. (2013), 'The dark side of NY-LON: financial centres and the global financial crisis', Urban Studies, 50(13), 2736-2752.

World Bank (2017), 'GDP (current US\$)', accessed on: 7 March 2017, http://data.worldbank.org/.

Zademach, H. and R. Musil (2014), 'Global integration along historical pathways', European Urban and Regional Studies, 21(4), 463-483. 